\title{
Sensitivity to electrical stimulation of human immunodeficiency virus type 1 and MAGIC-5 cells
}

\author{
Etsuko Kumagai ${ }^{{ }^{*}}$, Masato Tominaga ${ }^{2}$ and Shinji Harada ${ }^{3}$
}

\begin{abstract}
To determine the sensitivities to low electrical potential of human immunodeficiency virus type 1 (HIV-1) and its target cells, HIV-1 and MAGIC-5 cells were directly stimulated with a constant direct current potential of $1.0 \mathrm{~V}$ (vs. $\mathrm{Ag} / \mathrm{AgCl}$ ). HIV-1 was incubated for $3 \mathrm{~h}$ at $37^{\circ} \mathrm{C}$ on a poly-L-lysine-coated indium-tin oxide electrode, and then stimulated by an electrical potential. MAGIC-5 cells were seeded onto the electrically stimulated HIV-1 and cultured for 3 days at $37^{\circ} \mathrm{C}$. HIV-1-infected cells were measured by multinuclear activation via a galactosidase indicator assay. MAGIC-5 cells were also stimulated by an electrical potential of $1.0 \mathrm{~V}$; cell damage, proliferation and apoptosis were evaluated by trypan blue staining, cell counting and in situ apoptosis detection, respectively. HIV-1 was found to be damaged to a greater extent by electrical stimulation than the cells. In particular, after application of a 1.0-V potential for 3 min, HIV-1 $1_{L A I}$ and HIV-1 ${ }_{K M T}$ infection were inhibited by about $90 \%$, but changes in cell damage, proliferation and apoptosis were virtually undetectable. These results suggested that HIV-1 is significantly more susceptible to low electrical potential than cells. This finding could form the basis of a novel therapeutic strategy against HIV-1 infection.
\end{abstract}

Keywords: HIV-1 infectivity, electrical stimulation, indium-tin oxide, poly-L-lysine

\section{Introduction}

Infection with human immunodeficiency virus type 1 (HIV-1), the causative agent of acquired immunodeficiency syndrome (AIDS), leads to depressed cellular immunity and can result in co-infection with opportunistic pathogens and severe disease (Gottlie et al. 1981,; Masur et al. 1981,; Aboulafia 2000,; Picker et al. 2006,). The available treatments for HIV infection include antiHIV-1 therapy that inhibits the growth of the virus and prevents or reduces infection caused by various opportunistic pathogens. By using highly active anti-retroviral therapy, the morbidity and mortality rates in HIV-1infected individuals have dramatically declined (Hogg et al. 1997,; Palella et al. 1998,). However, such intensive anti-retroviral therapy has several drawbacks, including drug side-effects, the complexity of the therapeutic regimen and the appearance of resistant HIV-1 strains (Carr et al. 1998,; Colgrove et al. 1998,; Samati et al. 2002,). In 2010, human monoclonal antibodies, neutralizing over

\footnotetext{
*Correspondence: bear0289@eri.bbiq.jp

${ }^{1}$ Ex-Department of Biomedical Laboratory Sciences, Faculty of Life Sciences, Kumamoto University, 4-24-1, Kuhonji, Kumamoto 862-0976, Japan Full list of author information is available at the end of the article
}

90\% of circulating HIV-1 isolates, were identified (Wu et al. 2010; Z Zhou et al. 2010). The therapeutic use of multiple broadly neutralizing human monoclonal antibodies to HIV-1 would therefore be expected to block HIV-1 infection. However, effective vaccines based on this strategy are yet to be developed and much interest remains in developing therapies based on novel principles.

The effects of electrical stimulation on living cells have been extensively studied since the 1970s, and changes in cellular responses have been observed. In fact, cell membrane damage (Tominaga et al. 2007,), the regulation of cell proliferation (Kojima et al. 1991,; Yaoita et al. 1990,), gene expression of nerve growth factor (Koyama et al. 1996,; Koyama et al. 1997,) and neural and osteogenic differentiation (Kimura et al. 1998,; Mie et al. 2003,), have been reported in response to low potential loading. Furthermore, the combined effect of low potential stimulation and cisplatin administration caused cell death in HeLa cells (Manabe et al. 2004).

We are the only investigators to report of an electrical stimulation method as a means of protection against 
viral infection. One of our main findings was that the sensitivity to electrical stimulation was greater in chronically infected HIV-1 LAI (a T-cell-tropic strain of HIV) HeLa cells compared with uninfected HeLa cells (Tominaga et al. 2003,; Kumagai et al. 2004,). Another finding has indicated that reactive oxygen species (ROS) induced by electrical stimulation play a role in inhibition of HIV-1 infection (Kumagai et al. 2007). Despite many reports regarding the effects of electrical stimulation on cells, no previous studies have examined the effects of electrical stimulation on viruses. It is possible that if HIV-1 has high sensitivity to a low-electric potential compared with host cells, HIV-1 could be specifically inactivated by this treatment without any damage to host cells.

Poly-L-lysine (PLL) is a nonspecific attachment factor for cells, useful in promoting cell adsorption to solid substrates (Yavin et al. 1974,; McKeehan et al. 1984,; Atashi et al. 2009). Because PLL is a cationic agent, it enhances electrostatic interaction between negativelycharged ions of the cell membrane and culture surface. Coating indium-tin oxide (ITO) electrode surfaces with PLL increases the number of positively charged ions on the ITO electrode surface, which might allow adsorption of virus on the ITO electrode.

To determine the low-electric potential sensitivity of HIV-1 and cells, HIV-1 and MAGIC-5 cells were adsorbed onto a PLL-coated ITO electrode and directly stimulated with a constant direct current (d.c.) potential of $1.0 \mathrm{~V}$ (vs. $\mathrm{Ag} / \mathrm{AgCl}$ ). HIV-1 infectivity, cell damage, cell proliferation and the numbers of apoptotic cells were then examined to determine the sensitivities of HIV-1 and cells to electrical stimulation.

\section{Materials and methods \\ Preparation of virus}

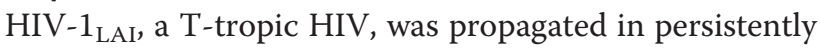
infected Molt4 cells as previously described (Koyanagi et al. 1986), and HIV-1 $1_{\mathrm{KMT}}$, a dual-tropic HIV, was propagated in persistently infected CEM cells as previously described (Morikita et al. 1997). Cell-free viruses were obtained by filtration of the cell supernatants through 0.45- $\mu \mathrm{m}$ filters (Millipore, Bedford, UK). Viruses were then aliquoted and stored at $-80^{\circ} \mathrm{C}$ prior to use. The concentration of HIV-1 $1_{\text {LAI }}$ and $\mathrm{HIV}-1_{\mathrm{KMT}}$ core $\mathrm{p} 24$ proteins were $211 \mathrm{ng} / \mathrm{ml}$ and $157 \mathrm{ng} / \mathrm{ml}$, respectively.

\section{Cells}

MAGIC-5 cells (CCR5 expressing the HeLa-CD4/long terminal repeat- $\beta$-galactosidase cell line; Hachiya et al. 2001) were used as target cells for HIV-1. Cells were maintained in Dulbecco's modified Eagle's medium (ICN, Costa Mesa, CA, USA) supplemented with $10 \%$ heat-inactivated fetal bovine serum (Gibco BRL, Grand
Island, NY, USA), $100 \mathrm{IU} / \mathrm{ml}$ penicillin and $0.1 \mathrm{mg} / \mathrm{ml}$ streptomycin.

\section{Electrodes and the application of electrical potential}

The application of electrical potential to HIV-1 was carried out with a three-electrode system using a potentiostat (Toho Technical Research, PS-06, Japan). The working electrode was an optically transparent glass plate (about $50 \times 50 \mathrm{~mm}$ ) sputtered with ITO (Kinoene Optics, Japan; Kumagai et al. 2007,; Tominaga et al. 2007). The ITO electrode, with a glass ring $(36 \mathrm{~mm}$ inner diameter, $15 \mathrm{~mm}$ in height) adhered to its surface, was cleaned by sonication in Contaminon $\mathrm{N}$ solution (Wako Chemicals, Japan), followed by rinsing with distilled water and autoclaving. $\mathrm{A} \mathrm{Ag} / \mathrm{AgCl}$ (saturated $\mathrm{KCl}$ ) electrode and a platinum electrode were used as reference and counter electrodes, respectively. All potentials are reported with respect to the $\mathrm{Ag} / \mathrm{AgCl}$ electrode.

\section{Adsorption of HIV-1 onto the ITO electrode surface}

To adsorb HIV-1 onto the ITO electrode surface, $500 \mu \mathrm{l}$ of a $0.01 \%(\mathrm{w} / \mathrm{v})$ of PLL solution (Sigma-Aldrich, P4832; the molecular weight of the polymer was 150,000 300,000 with an estimated1,026-2,052 repeating monomer units) was added and incubated for 5 min before removal by aspiration. The ITO electrode was thoroughly rinsed with sterile water and dried. Then, $1 \mathrm{ml}$ of HIV$1_{\mathrm{LAI}}$ or HIV-1 $1_{\mathrm{KMT}}$ solution was added to the PLL-coated ITO electrode and incubated for $3 \mathrm{~h}$ at $37^{\circ} \mathrm{C} / 5 \% \mathrm{CO}_{2}$.

\section{Multinuclear activation of a galactosidase indicator (MAGI) assay}

HIV-1 $1_{\text {LAI }}$ or HIV-1 $1_{\text {KMT }}$ that had adsorbed onto the PLLcoated ITO electrode surface was stimulated by a constant d.c. potential of $1.0 \mathrm{~V}$ (vs. $\mathrm{Ag} / \mathrm{AgCl}$ ) for 2-10 min. Then, MAGIC- 5 cells $\left(15 \times 10^{4}\right.$ cells/dish $)$ were seeded onto the electrically stimulated HIV-1 LAI, and cultured for three days at $37^{\circ} \mathrm{C} / 5 \% \mathrm{CO}_{2}$. After removing the supernatant, the HIV-1-infected cells were fixed and stained according to a previously described MAGI assay (Kimpton and Emerman, 1992,; Kumagai et al. 2007).

\section{HIV-1 p24 antigen assay}

HIV-1 LAI $_{\text {L }}(1 \mathrm{ml})$ solution was added to the PLL-coated ITO electrode, and incubated for $3 \mathrm{~h}$ at $37^{\circ} \mathrm{C} / 5 \% \mathrm{CO}_{2}$. After washing twice with PBS, HIV-1 $1_{\text {LAI }}$ that had adsorbed onto the ITO electrode surface was dissolved with $1 \%$ Triton $\mathrm{X}$. The amount of viral core $\mathrm{p} 24$ antigen was measured using an HIV-1 p24 antigen ELISA Kit (ZeptoMetric, NY).

\section{Measuring number of damaged cells}

To calculate number of damaged cells among electrically stimulated cells, cells were stained with $0.4 \%$ trypan blue 
dye for $5 \mathrm{~min}$. After the dye removal, the cells were washed three times with phosphate-buffered saline (PBS; pH7.2). The rate of cell damage was deduced after counting both stained (damaged) and unstained (undamaged) cells under a microscope.

\section{Cell proliferation assay}

To measure cell proliferation, a Cell Counting Kit (CCK; Dojindo, Kumamoto, Japan) was used. MAGIC-5 cells $\left(15 \times 10^{4}\right.$ cells $/ 3 \mathrm{ml} /$ dish $)$ were seeded onto the PLLcoated ITO electrode and were cultured for $3 \mathrm{~h}$ at $37^{\circ} \mathrm{C}$. After application of a $1.0-\mathrm{V}$ potential for 2-7.5 min, the cells were cultured for three days in a $5 \% \mathrm{CO}_{2}$ incubator at $37^{\circ} \mathrm{C}$. CCK solution $(300 \mu \mathrm{l})$ was added to each ITO electrode, and incubated for $40 \mathrm{~min} 37^{\circ} \mathrm{C}$. Then, $100 \mu \mathrm{l}$ of the supernatant was removed from each ITO electrode and placed in three wells of a 96-flat well plate (Iwaki, Tokyo, Japan), and the absorbance was measured immediately at $450 \mathrm{~nm}$ using a microplate reader.

\section{Apoptosis assay}

Electrically stimulated MAGIC-5 cells were fixed with $4 \%$ formalin neutral buffer solution for $10 \mathrm{~min}$ at room temperature. Fixed cells were then assessed for apoptosis using an Apoptosis In Situ Detection Kit (Wako Chemicals). This assay is based on the TdT-mediated dUTP nick end labeling method (TUNEL method).

\section{Results}

\section{HIV-1 adsorption onto the ITO electrode}

The amount of HIV-1 adsorption onto the PLL-coated ITO electrode surface was examined as a preliminary experiment. HIV-1 $1_{\text {LAI }}$ (p24 antigen level, $211 \mathrm{ng} / \mathrm{ml}$ ) was added to four PLL-coated ITO electrodes and four PLL-uncoated ITO electrodes, and incubated for $3 \mathrm{~h}$ at $37^{\circ} \mathrm{C}$. The mean and standard deviation (SD) of HIV$1_{\mathrm{LAI}}$ adsorbed onto four PLL-coated ITO electrode surface was $14.1 \pm 0.6 \mathrm{ng} / \mathrm{ml}$, and the rate of absorption was about $6.7 \%$. When the electrode was not coated with PLL, HIV-1 $1_{\text {LAI }}$ did not adsorb onto the electrode surface.

\section{HIV-1 infectivity after electrical stimulation}

HIV-1 $1_{\text {LAI }}$ or HIV-1 $1_{\text {KMT }}$ were incubated for $3 \mathrm{~h}$ on the PLL-coated ITO electrode, which was stimulated by a constant d.c. potential of $1.0 \mathrm{~V}$ (vs. $\mathrm{Ag} / \mathrm{AgCl}$ ) for different time periods, ranging from 2-10 min. As shown in Figure 1, the rates of HIV-1 $1_{\mathrm{LAI}}$ and HIV-1 $1_{\mathrm{KMT}}$ infection progressively decreased with the duration of electrical stimulation, and both types of HIV-1 infection were virtually undetectable after $7.5 \mathrm{~min}$ of electrical stimulation.

The rates of HIV-1 $1_{\mathrm{LAI}}$ and $\mathrm{HIV}-1_{\mathrm{KMT}}$ inhibition were obtained from the infection rate of electrically

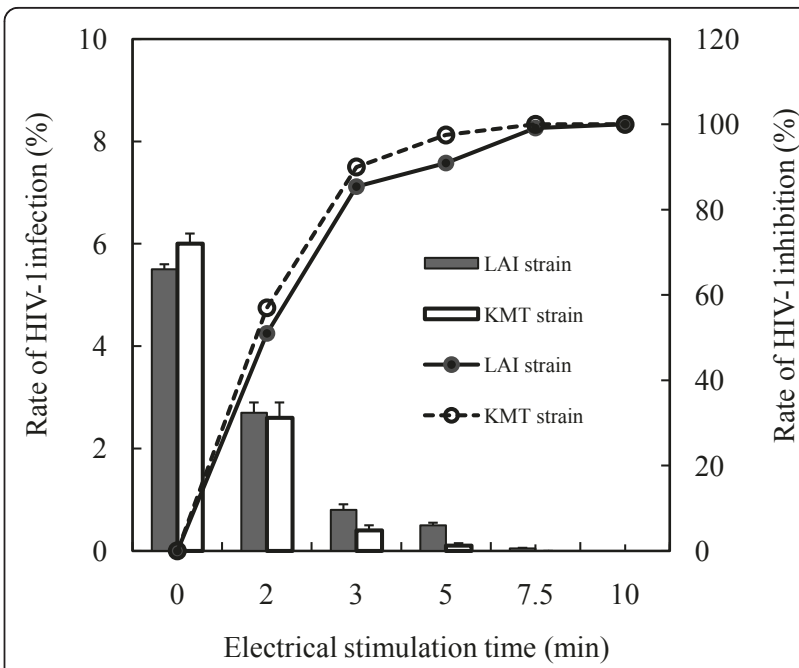

Figure 1 Effect of electrical stimulation on HIV-1 infectivity HIV-1 $1_{\text {LAl }}$ or HIV- $1_{\text {KMT }}$ was incubated for $3 \mathrm{~h}$ at $37^{\circ} \mathrm{C}$ on PLL-coated ITO electrodes and then stimulated by a constant d.c. potential of $1.0 \mathrm{~V}$ (vs. Ag/AgCl) for 2 to $10 \mathrm{~min}$. MAGIC-5 cells were then seeded onto the electrically stimulated virus. After culturing for 3 days at $37^{\circ} \mathrm{C}$, HIV-1-infected cells were examined using a MAGI assay. More than 3,000 cells were counted under a microscope. The rates of HIV$1_{\text {LAI }}$ and HIV-1 $1_{\text {KMT }}$ infection were defined as the number of stained cells divided by the total number of cells, as shown in the bar graph. The rates of HIV-1 $1_{L A I}$ and HIV-1 ${ }_{K M T}$ inhibition were derived from the infection rate of electrically stimulated and unstimulated virus, as shown in the polygonal line graph. Data represent the geometric mean \pm standard deviation of duplicate determinations.

stimulated and unstimulated HIV-1, respectively. After application of an electrical potential at $1.0 \mathrm{~V}$ (vs. $\mathrm{Ag} /$ $\mathrm{AgCl}$ ) for 2, 3 and $5 \mathrm{~min}$, the rate of $\mathrm{HIV}-1_{\mathrm{LAI}}$ inhibition was approximately $51 \%, 85 \%$ and $91 \%$, and the rate of HIV-1 $1_{\text {KMT }}$ inhibition was approximately $57 \%, 90 \%$ and $98 \%$, respectively.

\section{Cell damage induced by electrical stimulation}

MAGIC- 5 cells cultured for $3 \mathrm{~h}$ on the PLL-coated ITO electrode were stimulated by a constant d.c. potential of $1.0 \mathrm{~V}$ (vs. $\mathrm{Ag} / \mathrm{AgCl}$ ) for different time periods, ranging from 3 to $15 \mathrm{~min}$. As shown in Figure 2, the rate of damage of MAGIC-5 cells progressively increased with the duration of electrical stimulation. After electrical stimulation for 3 and $5 \mathrm{~min}$, the cells were barely damaged. However, about $91 \%$ of cells were damaged after 15 min stimulation.

\section{Cell proliferation after electrical stimulation}

Proliferation of MAGIC-5 cells after application of a 1.0 $\mathrm{V}$ (vs. $\mathrm{Ag} / \mathrm{AgCl}$ ) electrical potential is shown in Figure 3. Cell proliferation was unchanged in the presence of electrical stimulation at $1.0 \mathrm{~V}$ for $3 \mathrm{~min}$, whereas proliferation of the cells was markedly decreased in the presence of electrical stimulation at $1.0 \mathrm{~V}$ for $5 \mathrm{~min}$. 


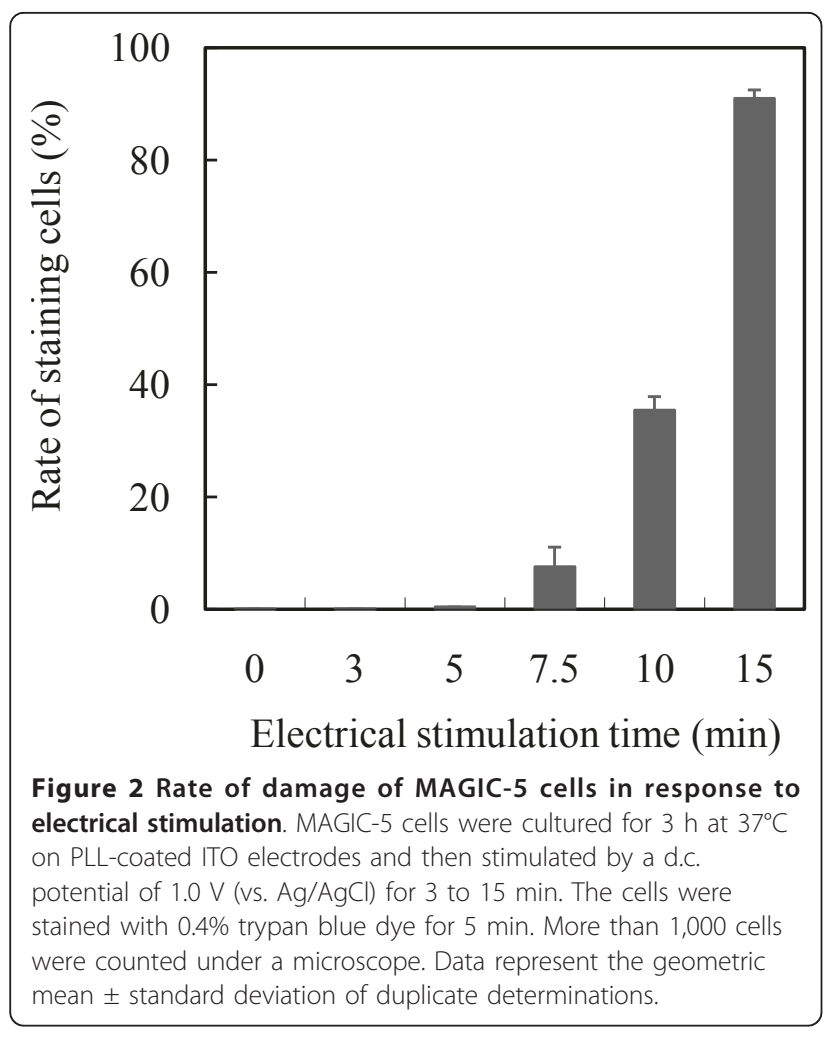

\section{Apoptotic cells after electrical stimulation}

The apoptotic rate of MAGIC-5 cells after application of a $1.0 \mathrm{~V}$ (vs. $\mathrm{Ag} / \mathrm{AgCl}$ ) electrical potential is shown in Figure 4. After electrical stimulation at $1.0 \mathrm{~V}$ for 5, 7.5 and $15 \mathrm{~min}$, the apoptotic rate of MAGIC-5 cells was about $0.1,2.8$ and $61 \%$, respectively. These rates were lower than the rates of damage of cells stimulated under the same conditions.

\section{Discussion}

A previous study reported that a lowering of cell membrane fluidity was caused not only by electrical stimulation (Kojima et al. 1991,), but also by certain medicines and by changes in temperature. Another study demonstrated that use of the local anesthetic xylocaine affected the fluidity of the cell plasma membrane, in turn affecting HIV-1 infectivity (Harada et al. 2005,). We predicted that the low potential sensitivity of HIV-1 would be higher than that of cells, because the fluidity of the viral envelope is lower than that of the plasma membrane (Harada et al. 2005).

To stimulate HIV-1 with a low potential, it is first necessary for the virus to be adsorbed onto an ITO electrode. However, HIV-1 does not possess the adhesion plaques exhibited by adherent cells, so was unable to adsorb onto the ITO electrode. Therefore, in our previous report (Kumagai et al. 2007), the effects of electrical stimulation on HIV-1 LAI were indirectly examined.

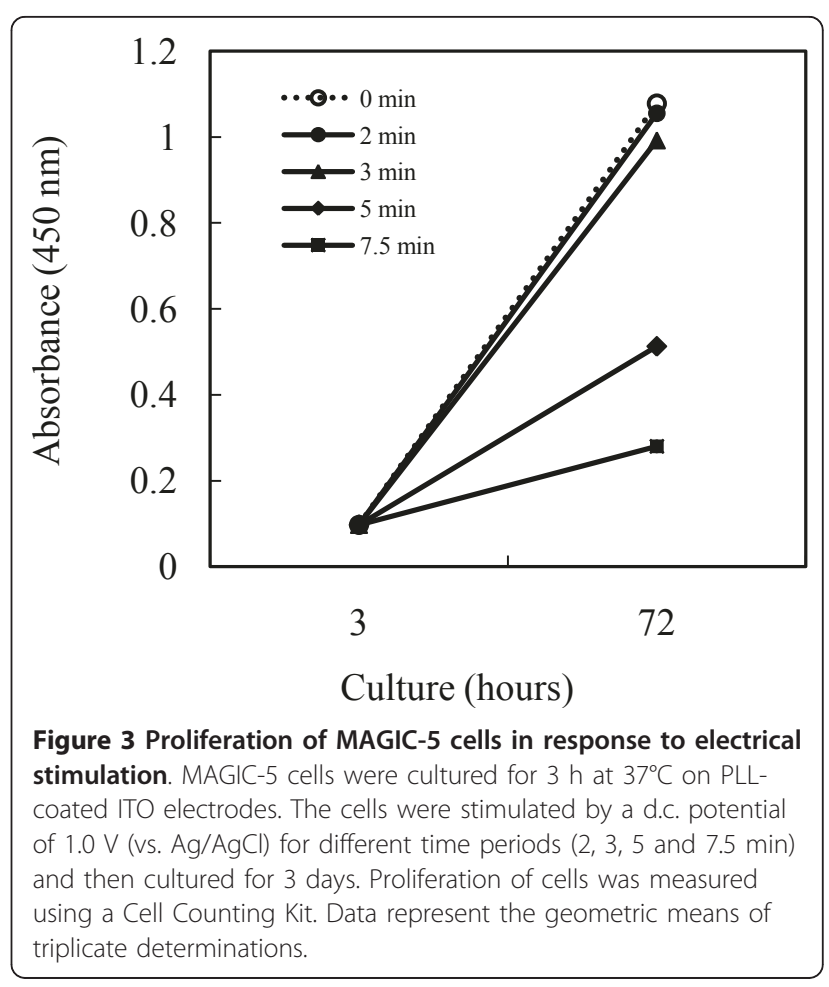

The research was carried out as follows: HIV-1 $1_{\text {LAI }}$ was adsorbed onto MAGIC-5 cells cultured on the ITO electrode, and then the HIV-1 ${ }_{\mathrm{LAI}}$-adsorbed cells were stimulated by a constant d.c. potential of $1.0 \mathrm{~V}$ (vs. $\mathrm{Ag} / \mathrm{AgCl}$ ). When the HIV-1 $1_{\mathrm{LAI}}$-adsorbed cells were stimulated at

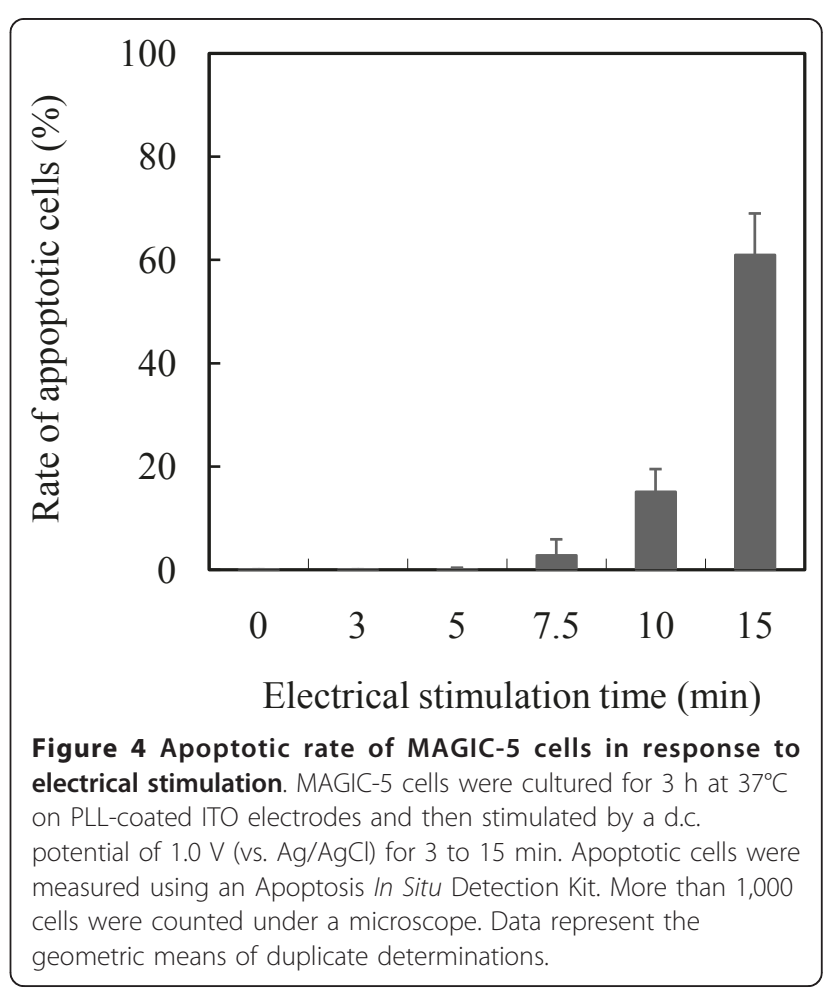


this potential for $5 \mathrm{~min}$, infection was inhibited by about $37 \%$, but the rate of damage of the HIV-1 $1_{\mathrm{LAI}}$-adsorbed cells was about $1 \%$. After application of a potential of $1.0 \mathrm{~V}$ for $5 \mathrm{~min}$, the mean fluorescence intensities of highly ROS and nitric oxide in the HIV-1 $1_{\mathrm{NL} 43-\mathrm{Luc}^{-}}$ adsorbed cells were significantly increased compared with those of unstimulated cells. These results suggested that the membrane of cells and virus envelopes were changed by electrical stimulation. As a result, the entry of viruses into cells might be blocked. However, it could not be completely ruled out that a few HIV-1 that had already entered cells at the point of stimulation might have been exposed to the effects of electrical stimulation. ROS that exhibit anti-viral activity (Corasaniti et al. 1995) might be involved in this process.

In the current study, HIV-1 and MAGIC-5 cells were directly stimulated with a constant d.c. potential of 1.0 $\mathrm{V}$ (vs. Ag/AgCl). The sensitivities of HIV-1 and the cells to electrical stimulation were then examined. PLL was used as an attachment factor for HIV-1 onto the ITO electrode, and about $7 \%$ of HIV-1 LAI was adsorbed onto the electrode surface by coating it with PLL. After adsorption, HIV-1 was directly stimulated with a potential of $1.0 \mathrm{~V}$, and then MAGIC-5 cells were seeded onto $\mathrm{HIV}-1$. After culturing the cells at $37^{\circ} \mathrm{C}$ for three days, the rate of HIV-1 infection was examined. MAGIC-5 cells were also used as the target cells of HIV-1, as they are easily infected with HIV and their cell morphology is easy to observe.

By directly stimulating $\mathrm{HIV}-1_{\mathrm{LAI}}$ or $\mathrm{HIV}-1_{\mathrm{KMT}}$ adsorbed onto the PLL-coated ITO electrode with the potential of $1.0 \mathrm{~V}$ (vs. $\mathrm{Ag} / \mathrm{AgCl}$ ), the infectivity of both types of HIV-1 was remarkably inhibited. For example,

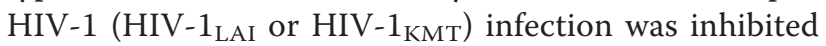
by about $90 \%$ by electrical stimulation of $1.0 \mathrm{~V}$ for 3 min. By application of the potential for $5 \mathrm{~min}$, the infection inhibition rate of HIV-1 $1_{\text {LAI }}$ (about 91\%) was more than twice that of HIV-1 $1_{\mathrm{LAI}}$-adsorbed MAGIC-5 cells. The MAGI assay is a method for determining inactivation of the $\beta$-galactosidase gene when HIV- 1 is integrated into the DNA of MAGIC-5 cells (Kimpton et al. 1992). The results of this assay indicated that lowering HIV-1 infectivity by electrical stimulation prevented HIV-1 from integrating into the DNA of the host cell. However, it remains unclear which part of this process, from adsorption of HIV-1 to cells to DNA integration, was damaged by electrical stimulation. With the currently available methodology, it is not possible to clarify this point. With future improvements in the ITO electrode, it may be possible to examine this is more detail.

Our results also demonstrated that there were no changes in the rate of cell damage, the apoptotic rate or the rate of cell proliferation in MAGIC-5 cells after electrical stimulation of $1.0 \mathrm{~V}$ (vs. $\mathrm{Ag} / \mathrm{AgCl}$ ) for $3 \mathrm{~min}$, compared with unstimulated cells. After application of the potential for $5 \mathrm{~min}$, damaged cells and apoptotic cells were virtually undetectable, however, the proliferation of cells also decreased by about $50 \%$, so low levels of DNA damage not detected by the apoptosis assay might have influenced the proliferation of cells. Taken together, these findings suggested that HIV-1 was significantly more susceptible to the electrical potential of 1.0 $\mathrm{V}$ (vs. $\mathrm{Ag} / \mathrm{AgCl}$ ) than cells.

In conclusions, we have shown that HIV-1 is significantly damaged by a d.c. potential of $1.0 \mathrm{~V}$ compared with cells. This remarkable difference in sensitivity between HIV-1 and cells to electrical stimulation could be useful not only for the elucidation of HIV control mechanisms but also for the development of novel therapies for HIV-1.

\section{Acknowledgements}

We thank Dr. M. Tatsumi for supplying the MAGIC-5 cells. We also thank S. Harima and $\mathrm{H}$. Terasawa for their technical assistance.

\section{Author details}

${ }^{1}$ Ex-Department of Biomedical Laboratory Sciences, Faculty of Life Sciences, Kumamoto University, 4-24-1, Kuhonji, Kumamoto 862-0976, Japan ${ }^{2}$ Graduate School of Science and Technology, Kumamoto University, 2-39-1 Kurokami, Kumamoto 860-8555, Japan ${ }^{3}$ Department of Medical Virology, Faculty of Life Sciences, Kumamoto University, 1-1-1 Honjo, Kumamoto 860-8556, Japan

\section{Competing interests}

The authors declare that they have no competing interests.

Received: 31 May 2011 Accepted: 8 August 2011

Published: 8 August 2011

\section{References}

Aboulafia DM (2000) The epidemiologic, pathologic, and clinical features of AIDS-associated pulmonary Kaposi's sarcoma. Chest 117:1128-1145. doi:10.1378/chest.117.4.1128.

Atashi A, Nadri S, Hafizi M, Soleimani M (2009) Role of poly-_-lysine-coated plates and fetal calf serum concentration in sheep chondroprogenitor cell culturing. J Artif Organs 12:118-122. doi:10.1007/s10047-009-0450-y.

Carr A, Samaras K, Burton S, Law M, Freund J, Chisholm DJ, Copper DA (1998) A syndrome of peripheral lipodystrophy, hyperlipidaemia and insulin resistance in patients receiving HIV protease inhibitors. AIDS 12:F51-F58. doi:10.1097/ 00002030-199807000-00003.

Colgrove RC, Pitt J, Chung PH, Welles SL, Japour AJ (1998) Selective vertical transmission of HIV-1 antiretroviral resistance mutations. AIDS 12:2281-2288. doi:10.1097/00002030-199817000-00009.

Corasaniti MT, Melino G, Navarra M, Garaci E, Finazzi-Agro A, Nistico G (1995) Death of cultured human neuroblastoma cells induced by HIV-1 gp120 is prevented by NMDA receptor antagonists and inhibitors of nitric oxide and cyclooxygenase. Neurodegeneration 4:315-321. doi:10.1016/1055-8330(95) 90021-7.

Gottlie MS, Schroff R, Schanker HM, Weisman JD, Fan PT, Wolf RA, Saxon A (1981) Pneumocystis carinii pneumonia and mucosal candidiasis in previously healthy homosexual men. Evidence of a new acquired cellular immunodeficiency. N Engl J Med 305:1425-1431. doi:10.1056/ NEJM198112103052401.

Hachiya A, Aizawa-Matuoka S, Tanaka M, Takahashi Y, Ida S, Gatanaga H, Hirabayashi Y, Kojima A, Tatsumi M, Oka S (2001) Rapid and simple phenotypic assay for drug susceptibility of human immunodeficiency virus type 1 using CCR5-expressing Hela/CD4 cell clone 1-10 (MAGIC-5). Antimicrob Agents Chemother 45:495-501. doi:10.1128/AAC.45.2.495501.2001. 
Harada S, Yusa K, Monde K, Akaike T, Maeda Y (2005) Influence of membrance fluidity on human immunodeficiency. Biochem Biophys Res Commun 329:480-486. doi:10.1016/j.bbrc.2005.02.007.

Hogg RS, O'Shaughnessy MV, Gataric N, Yip B, Craib K, Schenchter MT, Montaner JSG (1997) Decline in deaths from AIDS due to new antiretrovirals. Lancet 349:1294

Kimpton J, Emerman M (1992) Detection of replication-competent and pseudotyped human immunodeficiency virus with a sensitive cell line on the basis of activation of an integrated $\beta$-galactosidase gene. J Virol 66:2232-2239

Kimura K, Yanagida Y, Haruyama T, Kobatake E, Aizawa M (1998) Gene expression in the electrically stimulated differentiation of PC12 cells. J Biotechnol 63:55-65. doi:10.1016/S0168-1656(98)00075-3.

Kojima J, Shinohara H, Ikariyama Y, Aizawa M, Nagaike K, Morioka S (1991) Electrically controlled proliferation of human carcinoma cells cultured on the surface of an electrode. J Biotechnol 18:129-140. doi:10.1016/0168-1656(91) 90241-M.

Koyama S, Yanagida Y, Haruyama T, Kobatake E, Aizawa M (1996) Molecular mechanisms of electrically stimulated NGF expression and secretion by astrocytes cultured on the potential controlled electrode surface. Cell Eng 1:189-194

Koyama S, Haruyama T, Kobatake E, Aizawa M (1997) Electrically induced NGF production by astroglial cells. Nature Biotechnol 15:164-166. doi:10.1038/ nbt0297-164.

Koyanagi Y, Harada S, Yamamoto N (1986) Establishment of a high production system for AIDS retroviruses with a human T-leukemic cell line MOLT-4. Cancer Lett 30:299-310. doi:10.1016/0304-3835(86)90054-6.

Kumagai E, Tominaga M, Harada S (2004) Sensitivity of chronically HIV-1 infected HeLa cells to electrical stimulation. Appl Microbiol Biotechnol 63:754-758. doi:10.1007/s00253-003-1410-8

Kumagai E, Tominaga M, Nagaishi S, Harada S (2007) Effect of electrical stimulation on human immunodeficiency virus type-1 infectivity. Appl Microbiol Biotechnol 77:947-953. doi:10.1007/s00253-007-1214-3.

Manabe M, Mie M, Yanagida Y, Aizawa M, Kobatake E (2004) Combined effect of electrical stimulation and cisplatin in HeLa cell death. Biotechnol Bioeng 86:661-666. doi:10.1002/bit.20110.

Masur H, Michelis MA, Greene JB, Onorato I, Stouwe RA, Holzman RS, Wormser G, Brettman L, Lange M, Murray HW, Cunningham-Rundles S (1981) An outbreak of community-acquired Pneumocystis carinii pneumonia: initial manifestation of cellular immune dysfunction. New England Journal of Medicine 305:1431-1438. doi:10.1056/NEJM198112103052402.

McKeehan WL (1984) Methods for Preparation of Media, Supplements, and Substrata for Serum-free Animal Cell Culture. A.R. Liss, NY p 209

Mie M, Endoh T, Yanagida Y, Kobatake E, Aizawa M (2003) Induction of neural differentiation by electrically stimulated expression of NeuroD2. J Biotechnol 100:231-238. doi:10.1016/S0168-1656(02)00284-5.

Morikita T, Maeda Y, Fujii S, Matsushita S, Obaru K, Takatsuki K (1997) The V1N2 region of human immunodeficiency virus type 1 modulates the sensitivity to neutralization by soluble CD4 and cellular tropism. AIDS Res Hum Retroviruses 13:1291-1299. doi:10.1089/aid.1997.13.1291.

Palella FJ, Delaney KM, Moorman AC, Loveless MO, Fuhrer J, Satten GA, Aschman DJ, Holmberg SD (1998) Declining morbidity and mortality among patients with advanced human immunodeficiency virus infection. N Engl J Med 338:853-860. doi:10.1056/NEJM199803263381301.

Picker LJ (2006) Immunopathogenesis of acute AIDS virus infection. Curr Opin Immunol 18:399-40. doi:10.1016/j.coi.2006.05.001.

Sarmati L, Nicastri E, Parisi SG, d'Ettorre G, Mancino G, Narciso P, Vullo V, Andreoni M (2002) Discordance between genotypic and phenotypic drug resistance profiles in human immunodeficiency virus type 1 strains isolated from peripheral blood mononuclear cells. J Clin Microbiol 40:335-340. doi:10.1128/JCM.40.2.335-340.2002.

Tominaga M, Kumagai E, Harada S (2003) Effect of electrical stimulation on HIV-1 infected HeLa cells cultured on electrode surface. Appl Microbiol Biotechnol 61:447-450

Tominaga M, Nagaishi S, Kirihara M, Kumagai E, Harada S, Taniguchi I (2007) Frequency change-induced alternative potential waveform dependence of membrane damage to cells cultured on an electrode surface. J Biotechnol 129:498-501. doi:10.1016/j.jbiotec.2007.01.026.

Wu X, Yang ZY, Li Y, Hogerkorp CM, Schief WR, Seaman MS, Zhou T, Schmidt SD, Wu Longo NS, Mckee K, O’Dell S, Louder MK, Wycuff DL, Feng Y, Nason M, Doria-Rose N, Connors M, Kwong PD, Roederer M, Wyatt RT, Nabel GJ,
Mascola JR (2010) Rational design of envelope identifies broadly neutralizing human monoclonal antibodies to HIV-1. Sience 329:856-861. doi:10.1126/ science.1187659.

Yaoita M, Ikariyama Y, Aizawa M (1990) Electrical effects on the proliferation of living HeLa cells cultured on optically transparent electrode surface. J Biotechnol 14:321-332. doi:10.1016/0168-1656(90)90116-S.

Yavin E, Yavin Z (1974) Attachment and culture of dissociated cells from rat embryo cerebral hemispheres on polylysine-coated surface. J Cell Biol 62:540-546. doi:10.1083/jcb.62.2.540.

Zhou T, Georgiev I, Wu X, Yang ZY, Dai K, Finzi A, Kwon YD, Schied JF, Shi W, Xu L, Yang Y, Zhu J, Nussenzweig MC, Sodroski J, Chapiro L, Nabel GJ, Mascola JR, Kwong PD (2010) Structural basis for broad and potent neutralization of HIV-1 by antibody VRC01. Science 329:811-817. doi:10.1126/ science.1192819.

doi:10.1186/2191-0855-1-23

Cite this article as: Kumagai et al.: Sensitivity to electrical stimulation of human immunodeficiency virus type 1 and MAGIC-5 cells. AMB Express 2011 1:23.

\section{Submit your manuscript to a SpringerOpen ${ }^{\mathcal{O}}$ journal and benefit from:}

- Convenient online submission

- Rigorous peer review

- Immediate publication on acceptance

- Open access: articles freely available online

- High visibility within the field

- Retaining the copyright to your article

Submit your next manuscript at $>$ springeropen.com 